\section{WHERE SHOULD WAR CRIMES BE PROSECUTED?}

Political and military leaders should be subject to trial in England for alleged war crimes committed abroad. This unequivocal and controversial contention was the subject of a keenly contested debate at the IALS on May 27, with Philippe Sands QC, Joel Bennathan QC and Alex Bates speaking for the motion, and Iain Morley QC, Jonathan Kirk QC and Rodney Dixon opposing it. Speakers were allowed eight minutes, and the event was chaired by Joshua Rosenberg, the former BBC Legal Correspondent and legal commentator who is also a trained lawyer.

Philippe Sands affirmed his support for the principle of universal jurisdiction, under which any person allegedly engaged in war crimes anywhere in the world can be subject to proceedings in any country, including England. He said the world changed in the 1940s when the Geneva Conventions and the Genocide Convention were put place, and exceptions to the universal jurisdiction principle must not be made on the grounds that the states involved are considered to be too friendly or too powerful to antagonise.

A contrary position was taken by Iain Morley, who also said the world had changed - but in 1989 when the Berlin Wall came down and led to the disintegration of the Soviet Union. A new order emerged where ad hoc international tribunals dealt with atrocities that had taken place under regimes in countries including Rwanda, Sierra Leone, the former Yugoslavia and Cambodia (the latter still being in progress). Procedure and case precedents developed in consequence. It is better to make such trials international in nature than attempt to adjudicate in England on events that took place abroad with the all the difficulties involved in trying to establish the facts.

Supporting the motion, Joel Bennathan raised the issue of the UN-commissioned Goldstone Report into the Israeli incursion into Gaza which included amongst its findings the accusation that Israel committed actions amounting to war crimes. Israel is not a state party to the International Criminal Court and the events will not be referred there.

Jonathan Kirk took the view that no system of universal justice could ignore the realities of politics. The international ramifications of, for example, prosecuting George W Bush or Tony Blair in England would be enormous. He postulated that universal jurisdiction could have led to war crimes charges being brought against Churchill over Dresden and Munich, and Roosevelt over the dropping of the atomic bomb.

Alex Bates felt that the issue should not be addressed as an "either or" argument. Under the principle of complementarity the ICC should complement, rather than displace, domestic justice systems capable of prosecuting war crimes. A number of mechanisms were needed because limitations existed (for example the ICC cannot act on crimes which took place after 2002 and has restrictions on its jurisdiction).

He contended that international tribunals tend to go after the "big fish", and national courts have a role to play in prosecuting other important participants in war crimes. Universal jurisdiction can plug this particular gap. Furthermore, England has a strong history of participating in the prosecution of serious international crimes; offers a fair, speedy and relatively cost effective system of justice; has a contribution to make as a responsible member of the international community; and is in any event obliged to act in accordance with its international legal obligations under the Geneva Conventions etc.

Alex Dixon observed that the debate was not a new one, and universal jurisdiction has always tended to be influenced by the

\section{Articles}

Reforming European financial supervision and the role of EU institutions

Religious "irrationality" and civil liberties

Institute News

\section{Articles (cont'd)}

Recent developments in intellectual property law in Australia with some reference to the global economy

Duty of care and responsibilities of the management board of a German public company

politics of the day. There were clear legal obstacles to prosecuting foreign leaders in the UK, and other barriers existed including national security considerations, the problem of obtaining a jury conviction, and immunity issues surrounding heads of state. Arguably the best way forward lay in adopting a more limited interpretation of the principle of universal jurisdiction.

Members of the audience contributed a number of observations and opinions which reflected a broad range of views. Sceptics felt that the practical difficulties posed by staging a trial in England for alleged war crimes committed elsewhere - including persuading witnesses to attend and juries to convict - could render the whole process pointless, always assuming that politics did not intervene first. Those at the other end of the spectrum felt that putting George W Bush and Tony Blair on trial at the Old Bailey over their involvement in the Iraq war would help to prevent such conflicts in the future.

One pragmatist observed that the whole debate was sterile because this country was bound by its international legal obligations and should conform to them. Some audience members also drew attention to the presence in England of a category of individuals who have fled countries where genocide has been committed and are suspected of involvement. They cannot be sent back, but are not being investigated and remain here in limbo. If sufficient evidence against them existed, they should be tried in England.

A further criticism of universal jurisdiction was that it could be used by, for example, Arab or African states to mount trials on their own soil in order to further an anti-Western political agenda by charging politicians, military personnel etc from England and other countries with alleged war crimes. This point was dealt with by Philippe Sands in his summing up, who said the West must accept the risk of such prosecutions occurring. No-one should be above the law - including George W Bush, who authorised the practice of "waterboarding" which plainly amounted to torture.

Joel Bannathan stressed that laws should serve people's moral values. Juries would convict in cases involving war crimes overseas if the evidence was strong enough. Concluding the debate, Iain Morley said that the ICC existed because of the problems experienced by national jurisdictions in bringing witnesses to court and persuading juries to convict. Arguments had shifted away from universal jurisdiction and now centred round the operation of the ICC.

The motion was carried.

Julian Harris

Deputy General Editor, Amicus Curiae 